\section{Beware politicians bearing gifts}

The windfall for research in the proposed US stimulus package could backfire if not handled properly, warns David Goldston.

\section{T} he economic stimulus package now working its way through the US Congress looks to be a bonanza for scientists. The \$819-billion version written by Democrats in the House of Representatives, in concert with the administration of President Barack Obama, includes more than $\$ 13$ billion in research-anddevelopment spending. Although that figure will probably be smaller in the final bill, after negotiations with the Senate, scientists are likely to benefit immediately from the new political alignment in Washington.

The dollars slated for science are especially remarkable because they include funding for ongoing research programmes that are not usually seen as part of a stimulus effort. Indeed, science and university groups generally had lobbied only to include money to renovate laboratories because they didn't think research dollars would fit the stimulus criteria. Research grants give money to faculty members, who by definition already have a job, and to their graduate assistants, who may not even be US citizens. Research money can no doubt help the US economy now and in the longer term, but it hardly provides the same immediate boost as, say, hiring workers to build a bridge - or a laboratory, for that matter.

Not only that, the science numbers in the House bill are apparently higher even than the figures suggested privately by the new administration. This is presumably a bargaining strategy to ensure that spending does not sink too far in later compromises with the Senate.

So science advocates are right to be gleeful at this turn of events, but they should also be cautious. A stimulus bill is not the ideal vehicle for research spending, and, if scientists and their proponents aren't careful, the bill is a boon that could backfire.

First, being included in the stimulus measure could turn science spending into a political football. In general, federal support for science is something pretty much everyone in both parties agrees should be maximized, even if they haven't always followed through by providing the cash. The fight over the stimulus bill could erode that consensus, creating problems for the future. There are indications that this

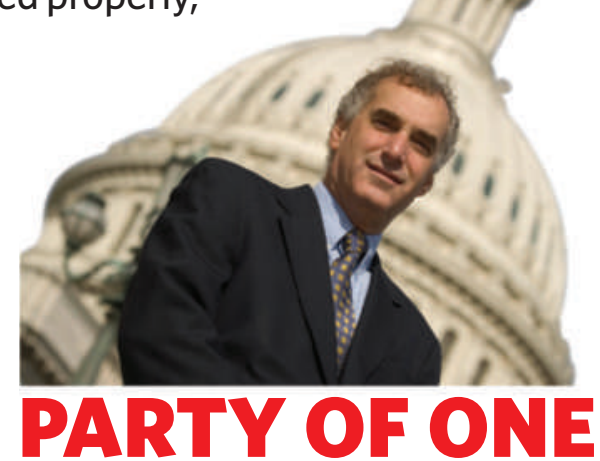

may already be happening. In a 24 January radio address criticizing the stimulus legislation, House Republican leader John Boehner (Ohio) complained: “There's $\$ 6$ billion for colleges and universities, many of which have multibillion-dollar endowments." Interestingly, he did not describe any of this spending as 'science', perhaps fearing that might make it sound more legitimate. But then again, Obama did not mention research when describing the stimulus plan in his radio address the same day, choosing to focus on more traditional projects that would affect more Americans directly.

Second, a stimulus bill usually consists mostly of one-off projects. The idea is to inject money into the economy now that will not create long-term obligations that could swell the deficit after the economy recovers. But that's not the hope for science spending. Science proponents, both inside and outside the government, want any increases for science agencies to become part of the agencies' base spending levels, to be built on in future years. Otherwise, a brief boom could be followed by a prolonged bust, which is more or less what happened to the National Institutes of Health (NIH) earlier this decade.

But there's no guarantee that the science money will be treated differently from other stimulus spending; it's not clear whether it will end up being a down payment on future increases. The first indication of the future won't come for another month or two when Obama releases his proposed budget for fiscal 2010, which will begin on 1 October. Hedging its bets, the House did include some money for NIH grants for the next fiscal year in the stimulus legislation, but it did not do that for any other agency, and the second year of NIH funding may not make it into the final bill.

The third, and perhaps most troubling issue, is that inclusion in the stimulus bill means the science money must be awarded with unusual, perhaps even reckless, speed. With the exception of the NIH, research agencies under the House bill will have to spend the funds within 120 days. That means that the National Science Foundation (NSF), for example, would have to allocate $\$ 3$ billion - a 50\% increase in its budget - in four months. As of last week, the NSF was still figuring out how it could do that - whether to make more awards in whatever grant competitions it happens to have ongoing when a bill is signed, whether to revive worthy proposals from past competitions that were rejected because of lack of funds or whether to try some other strategy.

The problem is magnified for new programmes such as the Advanced Research Projects Agency-Energy, which would receive \$400 million in the House bill - one-third more than Congress had previously thought the agency needed to get started. The first decisions an agency makes tend to set its course for years to come. Forcing a new agency that doesn't yet have staff to figure out how to have an impact on the nation's energy problem and award a sizable amount of money in a few months is hardly the safest way to get going (see Nature 447, 130; 2007).

Moreover, spending under the stimulus bill will be under heightened scrutiny. The bill includes new watchdog and transparency provisions that will make any missteps easier to catch and more widely known. Federal science programmes are generally viewed as well managed - that's one reason they are widely supported in Washington. Any mistakes made with stimulus money may well do disproportionate damage to agencies' reputations, and mistakes are more likely with the unusual time pressure. Legislators may also press science programmes to have more immediate results because they have been designated as stimulus efforts.

None of this means that it was a mistake to include science spending in the stimulus bill. Some version of it is certain to become law, and it provides the best opportunity to reverse the stagnation in science budgets that resulted from former President George W. Bush's prolonged stalemate with Congress. But it is hardly a risk-free approach. This is a case where, even in their euphoria, scientists need to be watchful of Congress bearing gifts.

David Goldston is a visiting lecturer at Harvard University's Center for the Environment. Reach him at partyofonecolumn@gmail.com. 